\title{
Studies on Hypoxia: XII. Detrimental Effects of Synthetic Polyribonucleotides on Epiphyseal Plates of Rats Exposed to Hypoxia
}

\author{
C. S. KOO,* M. K. KIM,* and S. S. HAN† \\ Department of Oral Biology, Department of Anatomy, and Program in Biology of \\ Aging, University of Michigan, Ann Arbor, Michigan 48104, USA
}

The effect of different doses of polyadenylic and polyuridylic acids (poly $A: U$ ) was studied in control rats and in rats exposed to hypoxia. In the control rats, administration of different doses of poly $A: U$ did not change the thickness of the epiphyseal plate or increase the incorporation of ${ }^{3} \mathrm{H}-p h e n y l a l a n i n e$ as judged using radioautography. Rats exposed to hypoxia showed a significant doserelated reduction in the thickness of the epi-

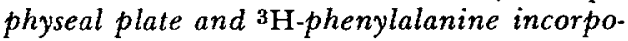
ration.

In a previous study, we observed that a prolonged exposure of rats to reduced oxygen tension created a reduction in the thickness of the epiphyseal plate in long bones. ${ }^{1}$ This was accompanied by a serious histological disorganization and a reduction in the incorporation of ${ }^{3} \mathrm{H}$-phenylalanine into osteogenic cells, chondroblasts, and fibroblasts of the region.

During the past several years, the use of certain polymeric forms of synthetic ribonucleotides in stimulating cellular activities has been attempted by a number of investigators who claim a predictable enhancement of protein synthesis in a variety of different systems. It has been shown that synthetic polyribonucleotides, when used in an appropriate quantity, were able to enhance protein synthesis in the pancreas ${ }^{2}$ and in the immune

This investigation was supported, in part, by USPHS Grant DE 03348 from the National Institutes of Health, Bethesda, Md.

Received for publication May 29, 1975.

Accepted for publication January $14,1976$.

- Present address: Seoul National University, College of Dentistry, Seoul, Korea.

+ Reprint requests: Cell Biology Laboratory, University of Michigan School of Dentistry, Ann Arbor, Mich 48104 . systems $^{3-7}$ as well as in interferon production. ${ }^{8}$ These developments represent a scientific breakthrough of a kind inasmuch as one of the major problems in the chemical treatment of many disorders (namely, cancer chemotherapy, immunosuppressive treatments after transplantation, and so forth) is the elimination of side effects potent drugs have on normal cells and organs that are vital to the full recovery of the patient.

The purpose of this investigation was to study the possible enhancement effects of polyribonucleotides on labeled amino acid incorporation into the connective tissue cells in normal and hypoxic rats under the conditions that have been shown to stimulate antibody synthesis by lymphocytes ${ }^{9-11}$ and amylase synthesis by parotid cells. 12

Results of our study show that, contrary to our expectations, the administration of different doses of polyadenylic and polyuridylic acids (poly A:U), which normally produced enhancement effects in other systems, fail to stimulate the incorporation of $3 \mathrm{H}$ phenylalanine into connective tissue cells of the epiphyseal plate in the control rats, and that poly A:U actually produced a suppressive effect on the amino acid incorporation into the same cells in hypoxic rats. These suppressive effects are dose dependent.

\section{Materials and Methods}

A total of $\mathbf{5 0}$ male Sprague-Dawley rats weighing about $150 \mathrm{gm}$ each were used throughout these experiments. They were assigned to pair-fed, control or hypoxic groups. Both experimental and control rats were then assigned to five groups of five rats each that received different doses of poly $A: U$ or vehicle as will be described in this 
section. Methods for feeding, administering ${ }^{3} H$-phenylalanine, and killing the rats were the same as those described in the preceding article. ${ }^{1}$ Similarly, procedures identical to those for the previous study were used with respect to hypoxic chambers, preparation of tissues for histometry and quantitative radioautography, and statistical treatment of results.

DOSAGE AND ADMINISTRATION OF POLYRIBONUCLEOTIDES.-Polyadenylic acid, potassium salt (poly A) a and polyuridylic acid (poly $\mathbf{U})^{a}$ were used in this investigation. An equimolar mixture of poly $\mathrm{A}(2.3 \mu \mathrm{mole} / \mathrm{mg})$ and poly $\mathrm{U}$ (2.8 $\mu \mathrm{mole} / \mathrm{mg}$ ) was made to form a homopolymer of poly $\mathrm{A}: \mathrm{U}$ in $0.15 \mathrm{M} \mathrm{NaCl}$ 30 minutes before injection. The final concentration of the poly $A: U$ was so adjusted that $1 \mathrm{ml}$ of the mixture contained $0.01,0.05$, 0.1 , or $1.0 \mathrm{mg}$ of the polynucleotides. The mixture was injected in volumes that would give the specified amount of poly $A: U$ included in $1 \mathrm{ml} / 100 \mathrm{gm}$ of body weight. Injection was done intraperitoneally 24 hours before the rats were killed. The same volume of $0.15 \mathrm{M} \mathrm{NaCl}$ was injected into all controls not receiving poly $\mathrm{A}: \mathrm{U}$.

\section{Results}

EFFECTS OF DIFFERENT DOSES OF POLY A:U ON THE THICKNESS OF EPIPHYSEAL PLATES AND ${ }^{3}$ H-PHENYLALANINE INCORPORATION INTO CONNECTIVE TISSUE CELLS IN THE CONTROL. RATS.Table 1 gives the mean thickness of the epiphyseal plate of rat femurs from rats that were given different doses of poly $A: U$. It shows that there were essentially no significant differences between the control rats and

* Miles Laboratory, Inc., Elkhart, Ind.

TABLE 1

EFFect of Different Doses of POLY A:U ON Thickness of Epiphyseal Plate of Control-Rat FEMUR EXPRESSED IN MICROMETERS

\begin{tabular}{cccr}
\hline $\begin{array}{c}\text { Poly A:U } \\
\text { (mg/100 } \\
\text { gm of BW) }\end{array}$ & Mean* \pm SD & Pf & $\begin{array}{r}\text { \% of } \\
\text { Control }\end{array}$ \\
\hline 0.0 & $431.3 \pm 58.6$ & & 100.0 \\
0.01 & $443.1 \pm 83.2$ & $>0.1$ & 102.7 \\
0.05 & $431.0 \pm 72.3$ & $>0.1$ & 99.9 \\
0.10 & $409.8 \pm 66.1$ & $>0.2$ & 95.0 \\
1.00 & $422.6 \pm 79.5$ & $>0.1$ & 97.9
\end{tabular}

Note: BW, body weight.

* Mean of five average measurements of five different rats.

† Comparison between control and experimental groups.

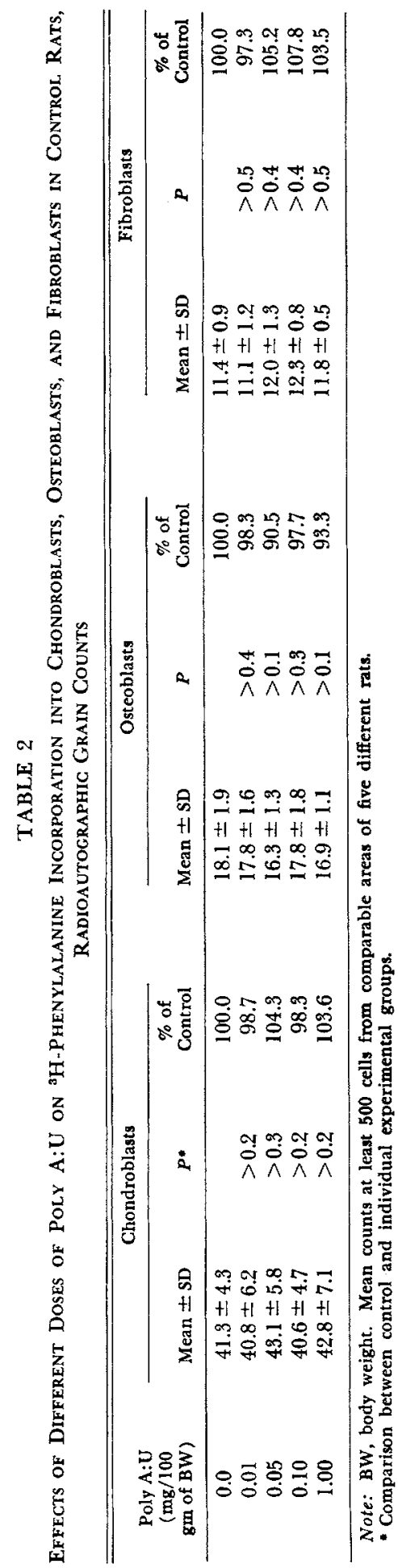


poly A:U-administered rats. Similarly, results from radioautographic grain counts of control rats (Table 2) also indicated that, although there were minor variations in the mean values, no significant differences existed between the control and experimental rats receiving various doses of poly $A: U$.

EFFECTS OF DIFFERENT DOSES OF POLY A:U ON THE THICKNESS OF EPIPHYSEAL PLATES AND ${ }^{3}$ H-PHENYLALANINE INCORPORATION INTO CONNECTIVE TISSUE CELLS OF HYPOXIC RATS.-In contrast to the lack of effects of poly $A: U$ both on the thickness and on the incorporation of ${ }^{3} \mathrm{H}$-phenylalanine into connective tissue cells of the epiphyseal plate in control rats, the injection of different doses of poly $\mathrm{A}: \mathrm{U}$ into hypoxic rats 24 hours before they were killed produced significant changes that were contrary to our expectations. Table 3 gives the mean thickness of epiphyseal plates in hypoxic rats, and shows significant reductions in mean values that were more or less related to the dose of poly $A: U$ that was administered. At $1 \mathrm{mg} / 100 \mathrm{gm}$ of body weight, the thickness of the epiphyseal plate was only $64 \%$ of the hypoxic rats that did not receive poly A:U. All of the mean figures were significantly different from the mean value of the hypoxic rat not receiving poly A:U.

When the mean number of silver grains over chondroblasts, osteoblasts, and fibroblasts of the epiphyseal plate were studied (Table 4), a progressive and dose-related decrease of grain numbers was observed in all three types of cells. The relative degree of such a reduction in grain numbers appeared to be similar among the three cell types. Therefore. the highest dose, namely, $1 \mathrm{mg} /$ $100 \mathrm{gm}$ of body weight, produced about 54 to

\section{TABLE 3}

Effects of Doses of Poly A:U on Thickness of Epiphyseal Plate of Rat femur after Chronic EXPOSURE TO HYPOXIA EXPRESSED IN MICROMETERS

\begin{tabular}{cccr}
\hline \hline $\begin{array}{c}\text { Poly A:U } \\
\text { (mg/100 } \\
\text { gm of BW) }\end{array}$ & Mean* \pm SD & P4 & $\begin{array}{r}\text { \% of } \\
\text { Hypoxic }\end{array}$ \\
\hline 0.0 & $312.4 \pm 53.7$ & & 100.0 \\
0.01 & $284.0 \pm 46.3$ & $>0.07$ & 90.9 \\
0.05 & $251.6 \pm 32.6$ & $>0.04$ & 80.5 \\
0.10 & $213.7 \pm 28.4$ & $>0.001$ & 68.3 \\
1.00 & $201.3 \pm 24.9$ & $>0.001$ & 64.4
\end{tabular}

Note: BW, body weight.

* Mean of five average measurements of five different rats.

+ Comparison between hypoxic and individual experimental groups.

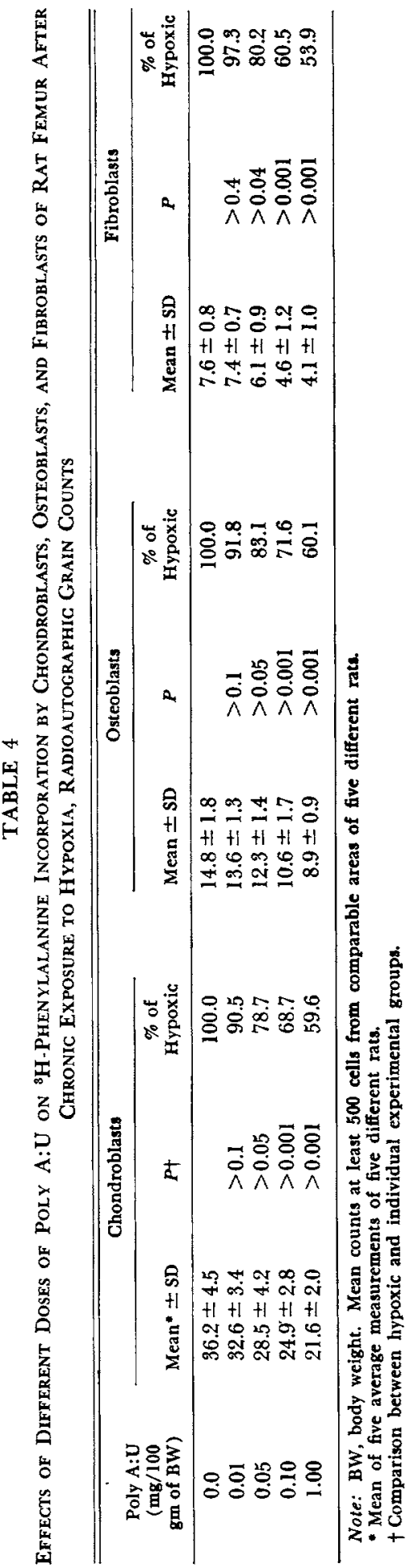


$60 \%$ of the value of the nonpoly A:U-treated values, with intermediate doses showing fewer differences.

\section{Discussion and Conclusions}

In recent years, poly $\mathrm{A}: \mathrm{U}$ has been shown to enhance the production of different types of proteins, including interferon, antibodies $3,4,6-11$ and secretory proteins of the digestive glands. ${ }^{12}$ Although stimulatory effects on protein synthesis in normal or control rats have been found to be variable, a clear-cut enhancement of protein synthesis has always been observed in cells of digestive glands that had been stressed by a variety of experimental conditions, including the administration of antimetabolites ${ }^{13}$ and exposure to hypoxia. ${ }^{12}$

Because relatively little is known about the mechanism by which poly $A: U$ stimulates cellular functions, the consistent enhancement of secretory protein synthesis in experimentally stressed organs is of great interest to us, and presents a unique future challenge in terms of the possible development of a means to stimulate protein synthesis in a predictable manner.

Results of this study are the only known data in which a generalized, suppressive effect of poly A:U on protein synthesis in several cell populations that have been stressed was observed. That such a suppressive effect was proportional to the dosage of poly A:U administered calls for serious consideration and further experimental work as to the utilitarian value of polyribonucleotides as agents capable of broadly stimulating protein synthesis under various conditions. This is particularly pertinent since we know very little about the molecular interaction between polyribonucleotides and cell membranes or the intracellular fate of polyribonucleotides in different cell types. Thus far, the only work in this area has been done by Schell14,15 who has shown that double-stranded nucleotides have easier access to the cytoplasm under certain in vitro conditions. Although certain physicochemical conditions that favor the entry of several polyribonucleotide preparations have been tested, poly $A: U$ used in our study has not been studied in detail. However, it should be pointed out that the same preparation, used under the same conditions, has repeatedly, produced an enhancement in antibody production ${ }^{6-11}$ and salivary protein synthesis.12,13 Therefore, the detrimental effect of poly $\mathrm{A}: \mathrm{U}$ on ${ }^{3} \mathrm{H}$-phenylalanine incorporation into epiphyseal plate cells of connective tissue origin should not be construed as evidence to question the impressive data produced in the past.

The results from this study do indicate the possibility that there could be dichotomous effects of poly $\mathrm{A}: \mathrm{U}$ that should be explored in detail in other systems as well, a point that deserves serious consideration particularly because of the recent trial use of the nucleotides in human patients. ${ }^{16}$ Accordingly, it may be suggested that any future use of poly $A: U$ as a generalized stimulant for protein synthesis will have to be looked at more closely and that the mechanism of poly A:U action on different types of cells should be better understood before a rational plan for a widespread application of the synthetic polyribonucleotides in the clinical enhancement of protein synthesis can be developed.

\section{References}

1. HAN, S.S.; Koo, C.S.; and KIM, M.K.: Studies on Hypoxia: XI. Long-term Effects on the Epiphyseal Plate-A Histometric and Radioautographic Study, J Dent Res 55: 367-371, 1976.

2. Kim, Y.G.: Effects of Hypoxia and Polynucleotides upon the Rat Pancreas: An Electron Microscopic and Biochemical Study, PhD thesis, University of Michigan, 1974.

3. Braun, W., and Nakano, M.: Antibody Formation: Stimulation by Polyadenylic and Polycytidylic Acids, Science 157: 819-821, 1967.

4. Braun, W.; Ishizura, M.; Yajima, Y.; Webr, D.; and Winchurch, R.: Spectrum and Mode of Action of Poly A:U in the Stimulation of Immune Responses, in BeER, $R_{\text {., }}$ and BRAUN, W. (eds): Biological Effects of Polynucleotides, New York: Springer-Verlag, 1971, pp 139-156.

5. Chess, L.; Levy, C.; Schmukler, M.; Smith, K.; and Mardiney, M.R., JR.: The Effect of Synthetic Polynucleotides on Immunologically Induced Tritiated Thymidine Incorporation: Amplification of Response, Transplantation 14: 748-755, 1972.

6. CONE, R.G., and Johnson, A.G.: Regulation of the Immune System by Synthetic Polynucleotides: IV. Amplification of Proliferation of Thymus-Influenced Lymphocytes, Cell Immunol 3: 283-293, 1972.

7. CONE, R.G., and JOHNSON, A.G.: Regulation of the Immune System by Synthetic Polynucleotides: III. Action on Antigen-Reactive 
Cells of Thymic Origin, $J$ Exp Med 133: 665-676, 1971.

8. Colry, G., JR.: The Induction of Interferon by Natural and Synthetic Polynucleotides, in: Davidson, J.N., and CoHN, W.E. (eds) : Progress in Nucleic Acid Research and Molecular Biology, Vol II, New York: Academic Press, Inc., 1971, pp 1-32.

9. Johnson, H.G., and Johnson, A.G.: Regulation of the Immune System by Synthetic Polynucleotides: II. Action on Peritoneal Exudate Cells, J Exp Med 1322: 649-664, 1971.

10. Schmidtke, J.R., and Johnson, A.T.: Regulation of the Immune System by Synthetic Polyribonucleotides: I. Characteristics of Adjuvant Action on Antibody Synthesis, J Immunol 106: 1191-1200, 1971.

1I. Johnson, A.G.; SChmidtKe, J.R.; MerRitt, K.; and HaN, I.H.: Enhancement of Antibody Formation by Nucleic Acids and Their Derivatives, in Plescis, O.J., and Braun, $W$. (eds): Nucleic Acids in Immunology, New
York: Springer-Verlag, 1968, pp 379-385.

12. KIM, Y.G., and HAN, S.S.: Studies on Hypoxia: X. Effects of Synthetic Polyribonucleotides on Pancreata from Hypoxic and Control Rats, an Electron Microscopic and Biochemical Study, Exp Mol Pathol 23: 43$58,1975$.

I3. Han, S.S.; HWang, L.; and Cho, M.I.: Enhancement of Functional Recovery by Poly. nucleotides in Fluorouracil-Treated Rat Parotid, I Dent Res (Special Issue A) : Abstract No. $391,1975$.

14. Schell, P.L.: Uptake of Polynucleotides by Intact Mammalian Cells: VIII. Synthetic Homoribopolynucleotides, Biochim Biophys Acta 240: 472-484, 1971.

15. Schell, P.L.: Uptake of Polynucleotides by Intact Mammalian Gells: XI. pH-Dependent Permeability Changes for Synthetic Ribopolymers, Biochim Biophys Acta 262: 467-475, 1972.

16. Johnson, A.G.: Personal communication, 1975. 